\title{
Horrible beauty and (un)easy submission: Melodrama and the gothic in Calvary
}

\begin{abstract}
This article examines Calvary (2014) as a gothic and melodramatic text - as an expression, more specifically, of pathetic melodrama and the Anglo-Irish gothic. As a pathetic melodrama, Calvary presents us with an apparently impassable situation, at the level both of the diegetic narrative, as well as the historical present. It also exhibits considerable suffering and pathos. These melodramatic features are articulated via affect in familiar ways, so that the film reproduces the moral occult and a regressive nationalism. The article argues, though, that Calvary's excesses are best understood as specific expressions of pathological melodrama, the bog gothic and the Cartesian gothic. In this respect, it is argued that Calvary's ostensive - dense and allusive - dialogue is a form of speaking suffering - a dark, but potentially productive game. All of Calvary's affective excesses, it is argued, are critical entities - ghostly witnesses, explosions and violent collisions of mind and body, which nonetheless cohere around particular histories, places and events. However much, then, Calvary may seem to accede to melodramatic redemption or gothic cliché, it is better understood, it is argued, as a form of submission - a necessary giving in and facing up to historical trauma and shame.
\end{abstract}

Keywords: melodrama, gothic, pathos, excess, affect.

Calvary (2014) is the second feature to be directed by John Michael McDonagh and the middle film of his suicide trilogy. Calvary tells the story of Father James Lavelle (Brendan Gleeson), the priest in a small town in the west of Ireland. During confessional, the confessor tells James he will kill him in a week's time. The confessor has been sexually abused by a priest as a child and now feels compelled to kill a good priest - James. James spends the week wrestling with how to respond to his potential killer, as well as trying to reconcile with his suicidal daughter and build bridges with an apparently disassociated and cynical set of parishioners. At Calvary's conclusion, James meets confessor on the beach. It is Jack, played by Chris O'Dowd. James reasons with Jack and reaches out to him as a friend, but Jack shoots and kills James nonetheless. The film's final scene is Fiona (James's daughter played by Kelly Reilly) visiting Jack in prison, facing him through the glass that separates them and picking up the telephone via which they can talk.

Reviews of Calvary are generally positive in Ireland and very positive in the UK. Three features predominate in the reviews: the strength of Brendan Gleeson's performance as Father James; a feeling that this performance rescues a film liable to collapse under the weight of its own excesses; and disappointment, sometimes disgust, that the film's director was arrogant and disloyal enough to declare Calvary 'not an Irish film' (McDonagh, in Clarke 2014b). ${ }^{1}$ Immediately, then, certain tensions are evident - between a measured performance within an unruly text, and an Anglo-Irish director who clearly wants to engage with questions of Ireland and Irishness, but who also wants to distance Calvary from Irish film. Moreover, further contradiction is apparent when in interviews during the period of Calvary's release, McDonagh positions himself as a literary director influenced by European filmmakers like Robert Bresson (in Clarke 2014a), but also as someone who 'always like(s) to entertain...(and) hate(s) little gems' (McDonagh, in O'Riordan 2014). 
In this essay, I want to examine in which ways these tensions may be evident, set in play or reconciled in Calvary. The primary way in which I'll do this is via genre and cultural mode. That is, I'll examine Calvary as a gothic and melodramatic text. This does not preclude Calvary from analysis as another type of genre film - for example and perhaps most obviously, as dark comedy, western or noir. To be sure, these are linked not separate areas of investigation in that at one level melodrama and the gothic are broad modes able to accommodate a variety of genres. In the analysis below, I will consider Calvary as melodrama and the gothic both in a broad sense, as well as as an example of particular expressions of these modes - that is and especially as family melodrama and the Anglo-Irish gothic. In refining the latter category still further, I'll argue that Calvary can be thought of as the Cartesian gothic, which is indeed an expression of dark comedy.

\section{Calvary and Irish film}

In her recent reviews of Irish film during the Celtic Tiger period (late-1990s to approximately 2008), Ruth Barton (2011, 2014b) identifies key trends. Firstly, there is a focus on the individual at the expense of the social and historical. These individuals, moreover, tend to be male - men who are dispossessed and marginalized, as well as at times irreverent and transgressive. The films frequently are internationally financed, and target themselves, or imagine, a global audience. Concomitantly, they exhibit a reduced version of Ireland and Irishness. In this respect, Barton (2011) argues, there has been a key shift during the Celtic Tiger period from Ireland conceived of as a post-colonial society to an emphasis on 'traumatic authenticity' (27). This recent cinema, Barton argues, is concerned primarily with working through trauma and exorcising the past. Difficult historical questions are safely memorialized - 'ghosts...laid to rest' (37) - and reduced to narratives and figures of victimhood and villainy.

Calvary in some ways continues the trends identified by Barton. Its primary focus is a man, Father James, and the film at one level is defined by irreverence. Calvary also makes clear efforts after traumatic authenticity, though this is less singular or all-encompassing than in the films considered by Barton. Calvary has three clearly traumatized characters - Jack, Fiona and Teresa (Marie-Josée Croze). Jack's trauma, on first analysis, is the broadest and most obviously historical in that it gives form to the on-going history of the clerical abuse of children in Ireland. This would appear to distinguish Calvary from Celtic Tiger films, which Barton notes are curiously silent on these events $(2014 b, 225)$. The extent to which Calvary examines and critically engages with this question is debatable. Certainly it can be argued both that James's death as a culminating and sensational sacrifice is an attempt at catharsis and laying to rest indeed of the horrors of abuse; and that for all its shocking opening, child abuse by the church then becomes one of a number of questions and traumas examined at pace by the film.

Also in keeping with the trends identified by Barton, it could be argued that the traumas experienced by Teresa and Fiona mostly are about the renewal of James. The remarkable strength exhibited by Teresa following her husband's death, we could say, is a lesson in faith for James, whose beliefs are tested throughout the film. And Fiona, as an 'icon of forgiveness' (Burgoyne 1994, 227), exists primarily, at one level of analysis, to teach James about fatherhood; or more broadly and problematically, to forgive the sins of various of Ireland's fathers. 
Calvary, then, is not completely separate from the Celtic Tiger films which precede it. However, while the arguments outlined immediately above are applicable to the film, they cannot explain entirely its form and effect. For example, while Calvary in some ways and like some Irish films which have preceded it, is a relentless 'assault on the Catholic church' (Barton 2011, 29), it is also an attempt at renewal - which might seem again to take it toward melodramatic regression and forgetting. The film, however, is both linear - counting down the days to its climax - and, it will be suggested below, anti-teleological. It is not just that ghosts remain, for all the death and forgiveness at the film's close; it is that a questioning and play on meaning and progress define key parts of Calvary. Likewise, for all the excessiveness of Calvary's characters, they cannot be placed singularly into melodramatically psychic roles. James to be sure is confused and haunted, but he is not emasculated or understood via victimhood. Also, while part of James's haunting is Jack and his dark plan, Calvary is not structured via villainy and virtue. The film is melodramatic, but not in these ways. Jack's monstrosity exceeds the limits of melodramatic villainy. Barton (2014b, 224) notes the influence of Beckett on Adam and Paul (2004). Beckett's force is also evident in Calvary. Below it will be considered how Jack's monstrosity can be understood with reference to Beckett's work; how Jack in Beckett's terms is a melancholic Cartesian comedian (Hansen 2009). Closely related to this is the influence of the gothic on Calvary.

\section{Calvary and the gothic}

From its earliest incarnations, 'cinema has availed itself of narrative situations and aesthetic effects derived from the Gothic tradition' (O'Rawe 2003, 190). Like melodrama, O'Rawe suggests that the gothic in cinema is a pervasive mode which can both accommodate various genres and also indicate specific generic tensions - tensions evident in the development and consolidation of film as a popular form, and in the negotiation, for example, between established European cultural traditions and emergent Hollywood genres. However, 'Gothicism...continue(s) to haunt the Irish symbolic order' (Backus, in O'Rawe 2003, 189) and in Irish culture, O'Rawe notes, tends to be associated with the specific concerns of the AngloIrish elite - an ascendancy class caught between the 'Scylla of Young Ireland and the Charybdis of Whig England' (191), whose anxieties and desires are given shape in the writing of Maturin (1780-1824), Le Fanu (1814-73) and Stoker (1847-1911). The Irish gothic, though, O'Rawe argues, is not a uniquely nineteenth century Protestant phenomenon. Its influence and internalization are evident well beyond this, in Catholic-nationalist fiction, and in the writing of Wilde (1854-1900), Joyce (1882-1941), Beckett (1906-1989) and Yeats (1865-1939).

In his article on the Irish gothic, O'Rawe's (2003) primary focus is the cinema of Neil Jordan. Jordan, like McDonagh, is greatly influenced by literature in his filmmaking. Moreover, his ambition to mix genres and modes has also resulted in his films being accused at times of unevenness. Jordan's interest, however, in questions of Irishness and Irish history and in the gothic as a way of investigating these questions abides. Three specific articulations of the gothic, O'Rawe argues, are evident across Jordan's films: derivation, refraction and dispersion.

Derivation refers to those films which most fully and recognizably inhabit particular instances of the gothic mode - for example The Company of Wolves (1984) and Interview with the Vampire (1994). Refraction is when the gothic is refracted through a number of hybridized genres; and dispersion is when particular gothic motifs and citations appear across a single film, which might also exhibit heightened gothic moments. 
The analysis which follows is interested in the gothic as an Anglo-Irish and Irish mode, with a particular resonance perhaps for the west of Ireland. It examines how the gothic is refracted in a film which combines elements of the western, noir, thriller, comedy and family melodrama - and does indeed use the gothic to reconcile genres, as well as an apparent tension between the serious and the popular, European art and entertainment. It considers the gothic not only as refracted, but also as exhausted - pushed to the limits of its imaginings and idiom so that it turns and moves in perverse and unexpected ways. The analysis is interested in all parts of dispersal as O'Rawe defines it. Calvary certainly has its gothic citations and moments. It also exhibits a gothic sensibility that 'issues from the widespread anxieties of times of stress' (O'Rawe 2003, 197). In this sense, Calvary is evidence that the gothic continues to haunt the Irish symbolic order. There is no shortage of ghosts in Calvary, it will be considered. Not all of them, following Barton, are laid to rest. As in the films of Neil Jordan and in his 'gothic vision' (O'Rawe 2003, 189), Calvary is not entirely comfortable with the idea of progress, and in some ways indicates that 'the end of history...is merely the beginning of new histories and new anxieties' (O'Rawe 2003, 189).

\section{Calvary and melodrama}

This hesitancy and anti-teleology would distinguish Jordan's films and Calvary from melodrama as Barton (2011) defines it in her analysis of Celtic Tiger films - that is, melodrama as resolved, regressive and reductionary. For Ben Singer (2001), this mostly would be action, as opposed to pathetic, melodrama. Calvary exhibits some features of action melodrama, but is mostly pathetic melodrama. Some definition here of these terms might help. Generally speaking, the most standardised accounts of film melodrama are to be found in Neale (2000, 196-197), Singer (2001, 44-49) and Williams (1998, 65-80). Singer and Williams both produce five-fold definitions of film melodrama. Singer argues that if a film shows evidence of two of his five defining features - pathos, overwrought emotion, non-classical narrative structure, sensationalism, and moral polarity - it can be defined as melodrama. Williams argues that five recurring features of film melodrama are that: it combines pathos and action as a means of producing moral legibility; it begins and ends in spaces of innocence; it focuses on victimheroes, recognising their virtue; it features characters who embody psychic roles organised around good and evil; and it uses realism to its own ends, in so doing appearing modern or contemporary.

Singer and Williams' five-fold models overlap and work well together. This is with the exception of Williams's emphasis on the 'dialectic' of pathos and action. Singer argues that most film melodramas do not depend on a dialectic of pathos and action to produce moral legibility. Instead, a distinction can be made between pathetic melodramas - high on pathos and low on action - and action melodramas, which are oriented to action but almost devoid of pathos. Both forms strive for moral clarity; but the former type tends to avoid moral polarisation in favour of complexity or 'moral antinomy' (Singer 2001, 54). Singer also considers the distinct but not absolute differences between action and pathetic melodrama when he discusses the centrality of 'situation' to most film melodrama (2001, 41-44). Singer notes that Lea Jacobs (1993) identifies two types of situation in film melodrama. In what Singer calls classical melodrama (equivalent to what I refer to as action melodrama, above), situation is a 'striking and exciting incident that momentarily arrests narrative action' (Singer 2001, 41) and which is familiar to the frozen 
tableaux and close-ups of, respectively, stage melodrama and television soap opera. In Hollywood melodrama (equivalent to pathetic melodrama), however, situation is the 'more diffuse condition of frustration or futility spanning almost the entire plot' (43). In these pathetic melodramas, impasse is generated, action is suspended, characters experience life crises and are unable to move directly towards their goals (43).

By these definitions, Calvary is in various ways a melodramatic text, and more pathetic than action-oriented melodrama. Situation in pathetic melodrama applies both to immediate narrative and broader cultural levels. With regard to the former, the two key situations are: What will James do with regard to the killer's plan?, and How will James reach peace with his daughter? These can't be divorced from the broader situation which is Ireland-church-economy. Situation in some way applies to all the film's characters, but the three key sufferers are James, Jack and Fiona. Further and as I note above, while there is no villain or obvious psychic play between good and evil, Calvary does have a virtuous and beleaguered hero at its centre. In western genre terms, James is a lonely figure living an austere life on the edge of town; a principled man who won't walk away from impossible duty or the film's final showdown. In these terms, Calvary is a conservative and occulted text. James's presence and performance constitute the moral occult (Brooks 1976), an attempt, however ill-fated, to fill the void left by de-sacrilization.

This reading, as I noted earlier in reference to Barton's $(2011,2014 b)$ analysis of Celtic Tiger films, cannot be discounted entirely. Moreover it may help to explain both the positive reaction of some church representatives to Calvary (in McGreevy 2014), as well as the frustrations exhibited by some reviewers. For these reviewers, James's performance of wounded virtue and manifest destiny is monumental, but threatens to be undone by the excesses of characterization (in terms both of quantity and quality) and plot - pathetic melodrama's non-classical narrative structure being pushed too far for some. Indeed for these critics, to put James at the centre of something called pathetic melodrama might seem nonsensical or just wrong. What stands out and endures for them perhaps is James's doggedness and integrity and the surety of his morality whatever his failings. Alongside this and equally important in producing the moral occult, are the spectacles of James's presence and face.

A strong and moral (and usually taciturn) face is romanticized and made timeless inseparably from the land in the western. It speaks of a man uncorrupted by words, women, domesticity, the east, modernity and all it implies. These value based and gendered distinctions apply well beyond the western; and in the context of genre, mode and critical distaste, it's noteworthy that strong masculine faces in early US cinema were praised by some for helping to distance the new screen medium from the excesses of stage melodrama (Gledhill 1987, 34). ${ }^{2}$ James's face, however, also cries, and speaks as excessively as Calvary's other characters; and its silences speak of powerlessness, not manly restraint. Moreover, on the key occasion James is placed in timeless wilderness (in the dream sequence I'll consider below), not only is the ontological status of the scene uncertain, but he's scared. This fear associated with the land points to Calvary's status as a gothic as well as melodramatic text.

In the growth and consolidation of melodrama in eighteenth century Europe, Gledhill $(1987,20)$ argues, gothic fiction played a central role in reconciling popular and bourgeois versions of the mode. In various ways, and as I note above in reference to early cinema and the work of O'Rawe 
(2003), the same may be true of Calvary, a text that for some struggles to reconcile the serious and the popular, restraint and excess. Calvary begins with spectacle and excess. The powerful, expansive and romantic move across hill, moor and sea, in particular may take us back to melodrama and the moral occult; and may be part of what prompts one reviewer to describe the film as 'organically Irish' (Moore 2014). I want to look at Calvary's opening now in some detail. In so doing, I'll show that it owes as much to the gothic as melodrama. I'll also show how it works as a powerful overture to the film's characteristic form and themes.

\section{An experiment in affect}

Calvary begins in silence with an epigraph on a black screen attributed to St Augustine: 'Do not despair; one of the thieves was saved. Do not presume; one of the thieves was damned'. This is followed by a close-up of a priest (Father James) in the confessional, cut at shoulders, softly lit in shadow, waiting for the penitent. After a long pause, the confessor speaks:

Confessor: I first tasted semen when I was seven years old.

Silence

C: Nothing to say?

James: It's certainly a startling opening line.

$\mathrm{C}$ : What is that, irony?

J: I'm sorry. Let's start again. What do you want to say to me? (faltering, hesitant). I'm here to listen to whatever you have to say.

C: I was raped by a priest when I was seven years old, orally and anally as they say in the court reports. This went on for five years, every other day for five years. I bled a lot, as you can imagine. I bled a terrible amount.

James closes eyes, leans back in pain and despair. Swallows, suppresses tears.

$\mathrm{J}$ : Have you spoken to anyone about this?

C: I'm speaking to you now.

J: I mean have you sought professional help?

C: Why? So I could learn how to cope? So I could learn how to live with it? Maybe I don't want to cope. Maybe I don't want to learn how to live with it. (spells out the words to indicate their uselessness).

Silence.

J: Why don't you make a formal complaint? You can testify.

C: The man's dead.

J: I don't know what to say to you. I have no answer for you, I'm sorry.

$\mathrm{C}$ : What good would it do anyway if he were still alive? What'd be the point in killing the bastard? That'd be no news. There's no point in killing a bad priest. But killing a good one, that'd be a shock (emphasis on shock) now. They wouldn't know what to make of that. I'm going to kill you father. I'm going to kill you because you've done nothing wrong. I'm going to kill you because you're innocent. Not right now, though. I'll give you enough time to put your 
house in order, make your peace with God. Sunday week, let's say. I'll meet you down on the beach there, down by the water there. (sniggering): Killing a priest on a Sunday, that'll be a good one. Do you not have anything to say to me Father?

J: Not right now, no. But I'm sure I'll think of something by Sunday week. (music begins as scene finishes).

As we hear the confessor leaving the confessional, a haunting, soft but powerful female voice accompanies the image of the priest's face, fearful and confused. The screen fades briefly to black and then lightens to reveal a romantic, beautiful pastoral scene: coastline, expanse of dark water, village, lush bog and farmland. The sun is breaking through cloud and it's unclear whether it's morning or evening. The music wells as if to meet the land and the overhead camera sweeps slowly. The first cut is to three low, flat, green, brooding or (re what I'll argue below) judgmental hills. The music has its steepest rise as we cut now to a frontal long shot of a single large green hill of the same type, the camera moving slightly toward it so that a degree of threat or portentousness is suggested. The lighting now is flat and grey. We cut to a ragged, ancient, black rock (bog beyond) coastline, the sea in tumult, crashing against the rocks, the camera sweeping slowly. The music wells again and we cut to a calmer sea, and then again to two dark, sentinel surfers, standing knee-deep in water and holding their boards.

The opening written words of Calvary point to a meditative and literary text - a film oriented to or originating from a European context and low both on narrative transparency and action. The written words are also metonymical of Calvary's director, who loves moral dilemmas, word games and literature, and considers himself a 'failed novelist' (Moore 2015). The written words also signal ambiguity, in keeping again with European art film indicators. They are ambiguous in terms of their source, in that while we may know the event and figures to which they refer Christ on the cross at Calvary, two thieves beside him - it's not clear to whom these precise words are attributable. There is no clear evidence that they were ever written or spoken by St Augustine. The key progenitors for the words are Luke's Gospel 23, The Repentance of Robert Greene, Master of Arts (Greene 1592 - which might be most responsible for the specific form the words take at the start of Calvary), and, in the late-modern period, Samuel Beckett's Waiting for Godot (1953). Thinking of these words as Beckett's - or as Beckett-esque - opens this opening scene, and Calvary, to greater uncertainty and possibility still. The words then become a performance - literary, theatrical, cinematic - and a deceptively ordered gesture of disorderliness. They become a setting off of the story, but also, from the outset, a setting free; a throwing out and up, the launch of a Beckett-esque kite.

Edward D. Miller (2012) describes Beckett's play and film That Time (1976/2000) as an exercise in kite flying. Miller follows Roger Caillois to argue that That Time re-orders the senses. It is a typically (to Beckett) ludic text which seeks to extend the boundaries of players' (actors, audiences) senses. During the game and performance, certain patterns, interiorities, memories become unexpectedly perceptible. The kite, for Caillois, performs an 'auscultation upon the sky' (Caillois, in Miller 2012, 150), allowing players to 'diagnose the ether' (Miller 2012, 150). To be sure, the play of words and their ability to bring forth, take away, reform ideas was at the front of Beckett's mind when he appropriated St Augustine's (non) quote for Waiting for Godot,

I am interested in the shape of ideas even if I do not believe in them. There is a wonderful 
sentence in Augustine...It is even finer in Latin than in English. 'Do not despair; one of the thieves was saved. Do not presume; one of the thieves was damned.' That sentence has a wonderful shape. It is the shape that matters. (Beckett, in Cunningham 2010)

The words which open Calvary, then, begin a Beckett-esque play on meaning and referent. The analogy with That Time can be pushed a little further, and it's hard to imagine McDonagh didn't have Beckett in mind when he conceived the opening of Calvary. Beckett describes Listener in That Time as 'an old white face'(Beckett, in Miller 2012, 151) lit in the dark. McDonagh presents us with the softly but clearly lit spectacle of a disembodied head interacting with a voice 'whose origins are shrouded' (Miller 2012, 150). As Miller suggests of That Time, both the face and its listening become the spectacle. This is 'what it looks like to listen...(to) bear(s) witness to the intricacies of listening and see(s) its various openings and trepidations...the effects that voices have on the skin, on the eyes and eyebrows, and on the mouth.' (153-155).

Not identically to the complex arrangement of That Time, but in some comparable ways, the actors' presence in this powerful opening scene is complicated. Gleeson/Father James seems especially open, penetrable (to paraphrase Jean-Luc Nancy - in Miller 2012, 154) by his interlocutor's voice - confined, shorn of body and the power both to move and look. Moreover, if the voice can be conceived as a departure from the body, the self and the psyche (Miller 2012, 153), then this seems especially so regarding the voice of James's unseen confessor - not only because of its hidden face and body, but because of its quality, tone and mode - heightened, it transpires, by McDonagh's decision to produce an amalgamated voice attributable to no real person or actor. This tactic does not diminish the 'girth' (Miller 2012, 155) or 'resounding presence' (155) of confessor's voice. Indeed it extends them - a dark gathering of ghosts making the 'intervention of the past into the present' (151) all the more felt. Further, if, as I'll argue, Calvary exhibits elements of the gothic as well as the thriller, then confessor's voice becomes monstrous as well as ghostly.

The movement out of the confessional into sweeping exterior shots of Irish hill and moor, bridged by haunting, numinous soundtrack, appears to be a move from devastating historical trauma and interior spectacle of pain to exterior national trans-historical spectacle. If we accept the Beckett analogy, this can also be understood as a move from unsettling modernism to the modern popular, Ireland as folk tale and postcard. The move, however, neither jars nor reassures entirely. We move into powerful affect that wells up and threatens to overwhelm. Calvary here becomes more melodramatic and more gothic. If we conceive this move into trans-historical Ireland as melodrama, then the occulting here might promise, via excess and spectacle, to resolve the painful historical questions raised in the confessional.

However, to invoke Yeats (no stranger to bourgeois nationalist sentiment and the occult) rather than Beckett, the powerful beauty of hill and moor and the haunting musical accompaniment remain also terrible. James's shock, confusion and fear are heightened not diminished by the segue into lush Ireland and excessive affect. In keeping with other gothic texts (see for example Rueschmann 2005, 15), Calvary here figures nature and peripheral landscapes as overpowering and threatening as well as potential sources of strength and refuge. The highly affective images and music from this perspective become an intensification of the ghostly voices, the monstrosity and the suffering we witness and hear in the confessional. They are not merely compensatory or 
'inflated images that would sin by false extension' (Deleuze, in Probyn 2010, 78). They are romantic and passionate and menacing. As well as to the gothic and what this might imply, this leads us to affect as Elspeth Probyn (2010) defines it.

Affect, Probyn reminds us, affects us. It is not secondary or dispassionate. It moves us. It 'takes its toll on the body that writes and the bodies that read or listen' (76). It has the power to change 'the relays that connect word, gesture, memory, sound, rhythm, mobility, image, and thinking' (Connolly, in Probyn 2010, 77). The affect communicated in the opening of Calvary is specific but multiple. As we move from epigraph to the end of the title sequence, we see, hear and feel hesitation, anger, pain, suffering, shame, guilt, trauma, monstrosity and fear; beauty, romance, nostalgia, land, spirituality and ghostliness. These affects, to use Connolly's terms, are nodes or relay points which cohere around particular histories, places and events - the disasters of sexual abuse and economic collapse in late-modern Ireland; but also more broadly the violence and impacts of capitalism and colonialism in modernity, Ireland, Europe and beyond. These affects are about people and things -about the individualised story to follow Calvary's opening, and about something bigger than James and Jack and their confusion and suffering. Deleuze calls these affects 'entities' (in Probyn 2010, 78), and notes their passion and intensity in the writing of T. E. Lawrence ('Lawrence of Arabia', 1888-1935). Lawrence was a man larger than life, of and for his time. Aware of his own public image, he was also abandoned, beaten as a child and haunted by shame - shame partly fueled, Probyn (2010) suggests, by a feeling of fraudulence about the dashing image he had cultivated, and partly due to the secret of his rape.

Victims of rape, Probyn notes, frequently exhibit the capacity to detach themselves from their body in recounting their experiences. Probyn provides Deleuze's theorization of this process: 'The mind begins by coldly and curiously regarding what the body does, it is first of all a witness; then it is affected, it becomes an impassioned witness, that is, it experiences for itself affects that are not simply effects of the body, but veritable critical entities that hover over the body and judge it.' (Deleuze, in Probyn 2010, 80). This captures something of the affect communicated in Calvary's opening confessional scene, when Jack presents himself as a witness to his own rape, describing it in clinical, quasi-legal terms. Moreover, as well as in the dock, he puts his abuse on the stage or front page, becoming, almost, a passionate audience member to his own spectacular and perverse plan: 'That'd be a shock now! They wouldn't know what to make of that!' The dark monstrous pleasure Jack seems to take here pushes his suffering beyond the normal realms of sense and judgment - making it plausible that he takes no theoretical interest either in coping or revenge.

Jack's dark plan also serves to disperse pathos, shame and affect, making these critical entities all the more powerful for the way they 'hover over the body and judge it' (Deleuze, in Probyn 2010, 80). In this respect, Calvary is a profoundly 'juridicial' (Probyn 2010, 87) text. It asks us to bear witness to shock and aftershock. Many of the film's affective elements are critical entities - characters' faces, especially but not only that of James; James's large, omni-present, cassocked body; the film's excessive, passionate, dangerous and frequently dark dialogue. In this respect, the hill, moor and ghostly music are only the most obvious affective critical entities, hovering as they do over the film as a point of return, a shadow of fear, judgement and guilt.

As a powerful expression of fear and shame, the movement from confessional to land brings 
'into being an entity or an idea through the specific explosion of mind, body, place, and history.' (Probyn 2010, 81). The land and music, as well as being touristic and romantic Yeats-ian manifestations of a giving, nurturing Ireland, are also historical and critical entities. This is further supported by Derek Gladwin's (2014) analysis of the Bog Gothic. Peripheral landscapes in Ireland produce a 'horrible beauty that contradicts itself' (Gladwin 2014, 45), and are an ineradicable part of Ireland's traumatic and complicated past. ${ }^{3}$ In the Anglo-Irish gothic imagination, the bog in particular, argues Gladwin, has the capacity to be both source of sin and moral darkness as well as refuge and solace. It embodies the violence of colonial history and fears produced by modernity, but resists nonetheless unequivocal incorporation into modernity or colonialism. The bog is at once a colonized space and site of post or de-colonial resistance: '(I)ts doubling quality - paradoxically solid and liquefied - resists categorization and therefore management, organization, and control. Its status as a counterpart of both Irish culture and the land creates a kind of palimpsest that holds all of those past associations even while it continually adds new ones.' (Gladwin 2014, 42).

The hill, the moor, the bog, the numinous music, then, are protean critical entities. They will not go away, and will continue to haunt the future as well as the past. They do not only or in any straightforward way return that which has been repressed; just as the shame and fear they affect cannot be traced or attributed to any one source. This, as Gladwin's analysis indicates, is not to argue that Calvary's dark affects are without historical contexts. If the film's opening captures us, it's crucial, as Probyn argues, to ask why - exactly what has grabbed our interest? Calvary draws us in in various complicated ways, and especially via spectacle and affect. If we feel our heart pulled and our stomach tightened by the end of the title sequence, it might be easy to assume we've 'been had' (Doane 1991, 304); or, as I've suggested, that the literary promise of the film's start has been subsumed or overwhelmed by affective spectacle and sound and thus the moral occult (Brooks 1976).

This assumption would re-enact what Williams $(1998,49)$ regards as the fatal splitting of emotion and thought in the analysis of melodrama. Elspeth Probyn's theory of affect similarly helps us to understand how affect works in certain melodramatic and gothic texts. Probyn reminds us that affects concern emotions and ideas, and extends this argument, again, via Deleuze. Deleuze's hovering, ghostly critical entities 'arise out of a violent collision of mind and body' (Probyn 2010, 80), belonging entirely to neither. Affects in this regard are not merely the 'eyes of the mind, but its Powers and Words' (Deleuze, in Probyn 2010, 81). T. E. Lawrence's expression of shame, Deleuze argues, pushes body and language to their limits, making language work differently. It is a shame, he suggests, that is 'consubstantial with being and reveals an insolent beauty that shows... at what point the coming out of shame was easy, at least for a moment' (Deleuze, in Probyn 2010, 81).

This theory of affect as a pushing of body and language to their limits is close to Beckett's interest in the shape of ideas and his desire to re-order the senses, to which I refer above. Jim Hansen (2009) argues that in thinking through questions of history and modernity, Beckett worked primarily within the architecture of the Anglo-Irish Gothic, re-fashioning 'worn-out' (132) tropes and, as a 'melancholic Cartesian comedian' (134), pushing the obsessive oppositions of the gothic imaginary to 'insane extremes' (135). In these respects, all parts of Calvary's opening are an 'auscultation' (Caillois, in Miller 2012, 150); are powerfully affective 
and provocative. Following Beckett, as well as Probyn and Deleuze's theories of affect, the shape of the words as a kite in Calvary's epigraph transcends conventional notions of the literary, and brings the written word fully into the realm of affect.

\section{Problematically oral: speaking suffering}

The opening of Calvary, then, from confessional to timeless and touristic coastline, is spectacular, uncertain and excessive. Written and spoken words are key parts of this excess, and the latter especially predicts a distinguishing feature of the film - its heavy, dark dialogue as a key part of Calvary's unusually high 'ostensiveness' (Drake 2006, 87). The spoken wordiness of Calvary also marks it out from other globalized art films and family melodramas in recent times. In keeping with these films, Calvary focuses on suffering and trauma - exhibits, as I've noted, the 'traumatic authenticity' (Barton 2011, 27) of recent Irish film. It is also a 'post-traumatic' (Mroz 2016) text with an episodic, non-classical call and response structure. McDonagh refers to Calvary as the middle film of his suicide trilogy (Wigley 2014). David Gramling (2010) calls the middle film of Fatih Akin's love, death and the devil trilogy (The Edge of Heaven, 2007) an aphasic text with a fugue-like structure. The manifestation and possibilities of this aphasia and not-quite-matched call and response structure are more evident in pathetic than action melodrama, to use Singer's (2001) terms. In the pathetic form of the mode, situation and pathos are as likely to pervade as punctuate the text; morality can shift and be opaque; and characters frequently are inarticulate or mute.

Every character in Calvary is loquacious not mute; and the film's excessive dialogue is a key and complicated part of its meanings and pleasures. But it is an aphasic text nonetheless. Father James questions the value of meaning, ${ }^{4}$ but spends the duration of the film in search of authentic communication and human connection. Mostly he fails. Frequently he's manoeuvred into a corner: 'I'll have to think about that one'. When the two characters who refuse to see goodness in Father James (Simon, played by Isaach De Bankolé, and Brendan, played by Pat Shortt) tell him the church cannot face a history of racism, corruption and abuse, his responses are glib at best. In the film's dark opening scene, before Father James is again left speechless, speech is thrown back at him as inappropriate: 'What is that, irony?', and useless, when Jack refuses to engage with the language of coping. Moreover, the one person (excepting Stanton's - Gary Lydon - gift of a gun) James goes to for help (Bishop Montgomery, played by David McSavage) offers only a potent display of abstract reason and moral evasion. Almost every encounter in Calvary is a failed effort after communication. Moreover the film is anti-teleological and well as aphasic. Critical writing, argues Drake $(2006,93)$ 'overwhelmingly favours teleological modes of performance'; and this, as I've suggested, may help to explain some reviewers' displeasure in Calvary, the film's excesses distracting from its 'terrible logic' (Clarke 2014a). The closing montage in this respect is a conceit inasmuch as it seems both predictably unifying and a dark reminder of James's failures.

Calvary indicates its resistance to teleology in various ways. As well as James's 'Why does it have to mean anything?' (in the Holbein scene with Michael Fitzgerald (Dylan Moran) ), he's left speechless again in the confessional when Fiona rejects his fatherly, diagnostic advice that wisdom and meaning come with age. The film's most disturbing and illogical speech, though, belongs to Frank (Aiden Gillen), when he recounts to James the chance destruction of an infant's life in surgery. The story is quietly devastating, and is delivered with unnerving élan by Frank. 
He approaches James (in the bar's snug and at the start of a reckless drinking session) from the bar, unbidden. He's a man at ease, framed beautifully in a deep medium shot, drink in hand, dressed and groomed immaculately. There is soft and, on close attention, slightly discordant music playing in the bar. The scene is lit and coloured for warmth. Frank launches into a long story, its motivation unclear. He tells James of an anesthetist's mistake, when he (Frank) was a surgeon in Dublin. The mistake left a three year old boy without sight, hearing, speech, or physical sensation of any kind. Frank invites James to imagine the terror and helplessness of the boy when he came round from the anesthetic: 'Think of it. Nobody comes to rescue you. No light is turned on. You are in the dark. You try to speak, but you can't. You try to move, but you can't. You try to cry out, but you are unable to hear your own screams. You are entombed within your own body, howling with terror.' James stares at Frank, confused and incredulous. He exclaims, 'What the fuck?! Why the fuck would you tell me a story like that?!' Frank shrugs and smiles slightly, 'No reason'. Livid, James leaps up as if to attack Frank, who (comically, but also scared) adopts a martial arts defensive pose. Smartly, Frank turns and leaves the pub, remarking en route on the touchiness of some people, and wishing Brendan and Simon (at the bar) good luck.

This speech tells us quite a bit about Calvary's perverse and meditative form. Importantly, Frank is not completely stripped by the text of sympathy. At one point he defends James when he's verbally attacked by Simon; at another we see him alone and beaten by life, almost poetically framed in his cynicism. At the start of his unsolicited story, when he approaches James, pathos is a companion at least to cynicism and irony. James has submitted to drink and we'd be forgiven for expecting some degree of a fusion of suffering between the two characters. Suffering, argues Doane (2004), frequently allies with pathos; and pathos frequently is opposed to logos and ethos, which is one reason why it's often associated, pejoratively, with melodrama. But in some pathetic melodramas (her primary focus is the films of Todd Haynes), Doane argues, this order is subverted: 'Like the pathos of distance evident in Haynes' work, the yoking together of the apparently incompatible pain and speech, body and logos, seems to challenge the heavily entrenched opposition of emotion and intellect' (Doane 2004, 14).

This helps to explain Calvary's excessive form; how a film straining under the weight of its words can also be aphasic; how aphasia can also mean a setting free as well as a loss, a liberation from certain forms of speech and history. Part of the rationale of Doane's thesis is to show the messy and productive power of pathos - that in both affective and historical terms, it sometimes is more closely linked to than cut off from its normative others. Moreover, Doane's theorization of pathos as closely linked to pathology and an opening up of the 'possibility of speaking suffering' $(2004,14)$ seems particularly suggestive for an analysis of Calvary. Frank's speaking suffering as anti-teleological has no single origin or destiny. However, Doane's theorization of pathos and suffering as pathologies - as something dark, compulsive and potentially productive can be connected in Calvary to David Lloyd's analysis of Irish colonial modernity. By David Lloyd's $(2011,96))$ terms, Frank's abjection and 'passive submission to impulse' is a peculiarly Irish pathology and stereotype, linked in the nineteenth century Anglo-Saxon imagination to turbulence and instinct, sentiment and femininity, as well as to the idea of Ireland as a disordered and problematically oral culture. 
This stereotype endures in Calvary, and the film both exploits it and reflects on it. It accounts for some of the dissatisfaction - even cultural cringe embarrassment - among some Irish reviewers so that, I would argue, when reviewers say the film is caricatured, in the main, it's the most compulsive/impulsive figures they have in mind (i.e. Frank, Leo (Owen Sharpe), Milo (Killian Scott), Veronica (Orla O'Rourke) and Jack). As Lloyd indicates, this is about gender as well as ethnicity; so that the overly-smart and loquacious characters make Calvary too masculine - i.e. too laddish and irresponsible - but also not masculine enough: not measured, serious and autonomous enough, Gleeson being the guiding light in this respect. However, Frank at one level is no different from all of Calvary's characters, in that they all suffer and they all feel compelled to testify or bear witness to something in the company of Father James. Frank's testimony is one of the darkest, alongside that of Jack at the film's start. However, Frank's story seems not only to sit outside of logos, but also ethos. There seems to be no historical, environmental, contextual point to it. Its only logic, perhaps, is that it's the most excessive of the film's Cartesian games or nightmares - Frank's story being the logical and horrific destiny of the autonomous mind, 'entombed within your own body'. This is one way, via the gothic and specific theories of the post-colonial Irish gothic, that pathos and ethos combine in Calvary.

\section{The Anglo-Irish gothic...}

Returning briefly to Beckett, Jim Hansen (2009) argues that Beckett's critique of modern conceptions of autonomy is constructed within the architecture of the gothic, or more precisely the Anglo-Irish gothic. As well as creating subjects without autonomy who seek nonetheless autonomy, the gothic cultural imaginary, Hansen argues, focuses on gender anxiety and imperial dispossession, and returns repeatedly to confined women and wandering, exiled males. Thinking in particular of Frank's unsolicited story, Hansen notes Beckett's tendency to parody teleology, and describes him as a melancholic Cartesian comedian who pushes Cartesian binaries 'to such insane extremes' that Cogito ergo sum becomes cogito ergo demens (135). By Hansen's terms, James is also a figure of the Anglo-Irish Cartesian gothic. He has lost domestic affection, in that he loses his wife and flees the English domestic scene, unwittingly inflicting double domestic loss on his daughter. He seeks refuge in autonomy and the life of the mind - the infinite regress of the rooms of the mind, as Beckett would have it. This fantasy typically becomes a prison and a nightmare in all kinds of ways, but most shockingly via the intrusion of bodies: the abused body of Jack, and the cut, suicidal body of Fiona.

At points in the film and in its publicity stills, Fiona appears a familiar Anglo-Irish gothic figure, in green and red and windswept and on the moor; no more so perhaps than in Calvary's enigmatic dream sequence - one of the film's most heightened gothic moments and an instance of O'Rawe's (2003) gothic dispersion. ${ }^{5}$ This short sequence is powerfully affective and deeply ominous, and crystalizes Calvary's darkest themes. The scene cuts from James at the parochial house, beaten and bruised from his encounter with Brendan and Simon at the pub, and railing at Father Leary (David Wilmot) for his naivety. The cut to the dream scene is bridged by deep, rumbling extra-diegetic sound, if it makes sense to describe sound in a dream as extra-diegetic. A long shot of a large, lumpen, flat-topped hill (the hill Calvary uses as a motif and point of return - green, as Cecil Alexander's hymn has it, but in this instance, never far away) fills the screen as the camera moves toward it. It is dark and monstrous, threatening, like the sky above it. We cut to a close up (cut at shoulders) of James. He's walking across a moor, the same hill and sky behind him. The low rumbling noise is joined by the sound of screaming gulls. The wind is on 
James's worried face and the weather is closing on him. James looks down at something (we never see what) apparently unpleasant and crouches to look closer. The camera moves to show Fiona beside him, looking equally perturbed. She's in a green tweed coat, red hair blowing across her face. She exclaims, 'Oh, dirty thing!' and turns away, repelled. Her voice is hollow and reverberates to signal both dread and the status of the sequence as a dream. James looks back behind them, across the moor. He's concerned and says to Fiona, 'Let's go home'. Fiona looks back and asks, 'What is it?' James keeps walking and tells her, 'Nothing'. We then cut to the parochial house and the Saturday morning after the Friday night bar-brawl before. James is sprawled face-down on his bed. He's disheveled, half-undressed, bruises on the small of his back, his knuckles cut. The sun shines in and he begins to wake.

In thinking, then, of this dark dream, and of the land and the music and the more obviously affective elements in Calvary, I don't want to present these as the predictable gothic (the land as peripheral, menacing, loathsome, engulfing etc.) versus the complex Beckett-esque gothic. Beckett, Hansen shows, worked with obsessive, exhausted gothic tropes, just as the music and land at one level seems obviously regressive and nationalist. Beckett's Cartesian gothic and the bog gothic as defined by Gladwin can be thought of as linked compulsions or pathologies; as dark refuges; as precarious aspects of modernity; and as impossible assertions of autonomy. The bog and the moorland, Gladwin (2014) argues, are 'a central landscape in the Irish literary and cultural imagination that also reflects gothic themes and modes' (52). This may be especially the case, he suggests, in the West of Ireland (Calvary's setting and the setting for Stoker's first novel) as the historically contested space of Irish land identity. In the bog gothic, Gladwin argues, the land is equally romanticized, feared and revered - a protean, palimpsest site of fear and moral darkness, refuge and rebellion; always with the capacity to invoke dreadful dreams as it does for Arthur in The Snake's Pass (1890), and again for James in Calvary.

Fiona, as I've noted, is also repelled by something unseen on the moor in James's bog dream. However, however suicidal, she is not Hansen's confined gothic woman in Calvary. Neither is she melodrama's woman at the window (Doane 1987, 288) - though the final two times we see her near the end of the film, she is indeed at windows: the window of her office in London, and the window of a visiting/phone booth in the prison in which Jack is held. The former scene would seem to point to a figure moving on in a transnational text. The transnational, Gledhill $(2007,12)$ argues, is more likely to defer than transcend the national. In this respect, Fiona (like her father) might be characterized as a wandering and returning exile, who by the close of the film is back in Ireland, trying once more to forgive a damaged man. In this latter prison scene, Fiona to some degree is melodrama's icon of maternal forgiveness (Burgoyne 1994, 227) as well as a non-Irish nurturing woman. In recent Irish film, Barton (2014a) notes, post-colonial Ireland and patriarchy are renewed via non-Irish nurturing women. If Fiona only half fits this description - for all the unqualified love and forgiveness she sends James via the phone from her office, she is in London, and like McDonagh is only half not-Irish - Barton's observation is lent fuller support by the fully not-Irish (i.e. French) figure of Teresa, who shows remarkable faith and strength of character in the face of her husband's death; and who finally compels James to turn again to face his demon(s). 


\section{...and neo-melodrama}

This turning (when, at the airport, James returns instead of flying off to Dublin), I want to suggest, is James both not giving up and giving up. It is of course a submission of sorts to Jack's dark plan. It is, as the film's title suggests, James turning his palms to the sky in the final beach scene and being killed so that others' goodness might endure. In Williams' (1998) melodramatic terms, this is a return to innocence, but a provisional one - given Calvary begins with dark games and a glowering, uncertain pastoral scene, and ends only with a suggestion of hope. I want to suggest, though, that Calvary generally and in its final parts can be thought of as an effort after renewal. By Gledhill's (2014) terms, Calvary is a neo-melodramatic film. That is, it retains elements of the moral occult and tries to return itself to innocence, but also fails to dispel discomfort and guilt. Moreover, melodrama's combination with the gothic produces a film suffused with shame, which is also deeply juridicial (Probyn 2010). The hill and the moor and the music are a constant backdrop and point of return; one of the film's central characters, as it were: dark, menacing and amorphous; inescapable, spectacular and judgmental. The more obvious affective elements in Calvary are certainly clichéd. They are also, though, historical sites of memory and imagination, expressing familiar and less familiar fears and anxieties about late modernity and what home and autonomy might mean under changed circumstances.

The critical entity we spend the most time with in Calvary is James's face. What finishes the confessional scene and combines with music to bridge interior and exterior is James's profoundly affected face. The face, as I've noted, is confused, fearful, suffering, ashamed. It is a face, following Miller (2012), that shows trepidation - a fear for its own life, but more than this. It shows knowledge that something must be faced, faced up to; following Probyn (2010), that historical shame must be owned and confronted. James's devastated face in the confessional also gives shape to historical trauma. This too is what the exhausted tropes of Ireland, land, melodrama and the gothic do as we move out into the hill and the moor and the ghostly romantic past. If we are engulfed and seduced here, then following Gladwin (2014) and others, this is a contradictory process. The beauty here is 'insolent' (Deleuze, in Probyn 2010, 81) indeed, refusing to be tied to any one history or possibility. There are more trepidations than openings in James's face, as a ghostly voice leads us out into the land and what may be the start or finish of a day. But if there is comfort in these dark, passionate images and this song, then this may be an important form of submission, of a giving of oneself. This is what, at the film's close, James will do on the beach: throw away his gun, turn his palms upward, look straight into the face of Jack and tell him, on his knees, that he's his friend.

This may be the point in Calvary where 'coming out of the shame was easy, at least for a moment' (Deleuze, in Probyn 2010, 81). It is the opening that Jack's dark experiment in the confessional couldn't know and predict. It is Calvary's way of saying, especially in its affects, that history and shame, and a history of trauma and shame, exceeds us; precedes us and lives on. This is what the words and the sounds and the faces and the land give up: 'the gift of shame' (Probyn 2010, 89). Affect as a critical entity, Probyn argues, has the power to 'generate new ways of thinking about how we are related to history and how we wish to live in the present' (89). This is what Calvary asks us to feel, to examine, not to turn from. 


\section{Notes}

1. As Elsaesser (2015) notes, it's not unusual for a European auteur to attempt to distance him/herself from national film.

2. This process, Gledhill (1987) notes, was a contradictory one. Masculine subjective realism (i.e. a restrained performance of face) in early cinema was welcomed as preferable to emotional feminine melodrama. Not only was this a partial reading of stage melodrama, it was also at apparent odds (though perhaps all-a-one) with the way early dialogue in film was praised for its ability to lead cinema away from the excesses of melodramatic display. Moreover, notes Gledhill, this was when dialogue was most evident in 1930s US films more melodramatically oriented to female concerns.

3. Gladwin (2014) provides valuable details which I don't have space for here, including the late-nineteenth century Land War in the west of Ireland, as well as the fallout from Gladstone's 1881 Land Act.

4. Most emphatically when Michael Fitzgerald (Dylan Moran) tells James he can't interpret Holbein's The Ambassadors (1533), before declaring that owning it is what matters, and then urinating on it. The choice of The Ambassadors here seems apt given the painting's famous ambiguity and apparent play on developing relations between church and capitalism - maybe too apt (especially when combined with the pissing moment) for Calvary's detractors.

5. There is also a clear moment of gothic dispersion and citation (O'Rawe 2003) when James and Fiona share a joke about James's love of Irish folklore on the moor. Fiona moves between ribbing her father and reading a novel. The title of the novel is unclear (beyond being a Penguin Classic), but its cover is Henry Fuseli's The Nightmare (1781), a familiar image in the realm of gothic art and culture.

\section{Filmography}

Adam and Paul. 2004. Dir. Lenny Abrahamson. Ireland.

That Time. 2000. Dir. Charles Garrad. Ireland.

The Edge of Heaven. 2007. Dir. Fatih Akin. Germany/Turkey.

\section{References}

Barton, Ruth. 2011. The ghost of the Celtic Tiger. In Glocal Ireland: Current perspectives on literature and the visual arts, edited by Marisol Morales Ladrón and Juan F. Elices Agudo, 2638. Newcastle upon Tyne: Cambridge Scholars Publishing. Barton, Ruth. 2014a. From symbol to symptom: Changing representations of fatherhood in recent Irish cinema. In Masculinity and Irish popular culture: Tiger tales, edited by Conn Holohan and Tony Tracy, 183-194. Basingstoke: Palgrave Macmillan.

Barton, Ruth. 2014b. Between modernity and marginality: Celtic Tiger cinema. In From prosperity to austerity, edited by Eamon Maher and Eugene O'Brien, 218-229. Manchester: Manchester University Press. Brooks, Peter. 1976. The melodramatic imagination. New Haven: Yale University Press. Burgoyne, Robert. 1994. National identity, gender identity, and the 'rescue fantasy' in Born on the Fourth of July. Screen 35, no. 3: 211-234. 
Clarke, Donald. 2014a. Film review: Calvary. The Irish Times 11 April 2014.

http://www.irishtimes.com/culture/film/film-review-calvary-1.1755673.

Clarke, Donald. 2014b. Director of The Guard says Irish films are not 'intelligent'. The Irish

Times 15 September 2014. http://www.irishtimes.com/culture/film/director-of-the-guard-saysirish-films-are-not-intelligent-1.1929362.

Cunningham, David S. 2010. ' Do Not Presume': The fate of the other thief. The Christian

Century, no. 23. https://www.christiancentury.org/article/2010-03/do-not-presume.

Doane, Mary Ann. 1987. The 'woman's film': Possession and address. In Home is where the

heart is: Studies in melodrama and the woman's film, edited by Christine Gledhill, 283-298.

London: BFI.

Doane, Mary Ann. 1991. The moving image: Pathos and the maternal. In Imitations of life: A reader on film and television melodrama, edited by Marcia Landy, 283-306. Michigan: Wayne State University Press.

Doane, Mary Ann. 2004. Pathos and pathology: The cinema of Todd Haynes. Camera Obscura 19, no. 3: 1-21.

Drake, Philip. 2006. Reconceptualizing screen performance. Journal of Film and Video 58, nos. 1-2: 84-94.

Elsaesser, Thomas. 2015. European cinema into the twenty-first century: Enlarging the context? In The Europeanness of European cinema: Identity, meaning, globalization, edited by Mary Harrod, Mariana Liz and Alissa Timoshkina, 17-32. London: I. B. Tauris.

Gladwin, Derek. 2014. The bog gothic: Bram Stoker's 'Carpet of Death' and Ireland's horrible beauty. Gothic Studies 16, no. 1: 39-54.

Gledhill, Christine. 1987. The melodramatic field: An investigation. In Home is where the heart is: Studies in melodrama and the woman's film, edited by Christine Gledhill, 5-39. London: BFI. Gledhill, Christine. 2007. Genre and nation. In Genre and cinema: Ireland and transnationalism, edited by Brian McIlroy, 11-25. London: Routledge.

Gledhill, Christine. 2014. Introduction. In Revisiting film melodrama, edited by Dominique

Nasta, Muriel Andrin and Anne Gailly, 17-30. Brussels: PIE Peter Lang.

Gramling, David. 2010. On the other side of monolingualism: Fatih Akin's linguistic turn(s). The German Quarterly 83, no. 3: 353-372.

Hansen, Jim. 2009. Terror and Irish modernism: The gothic tradition from Burke to Beckett. Albany: State University of New York Press.

Jacobs, Lea. 1993. The woman's picture and the poetics of melodrama. Camera Obscura, no. 31: 121-147.

Lloyd, David. 2011. Irish culture and colonial modernity 1800-2000: The transformation of oral space. Cambridge: Cambridge University Press.

McGreevy, Ronan. 2014. McDonagh's Calvary praised by US archbishop as 'unforgettable'. The Irish Times 22 September 2014. http://www.irishtimes.com/culture/film/mcdonagh-s-calvarypraised-by-us-archbishop-as-unforgettable-1.1936926.

Miller, Edward D. 2012. The performance of listening: Samuel Beckett's That Time. Cinema Journal 51, no. 3: 150-155.

Moore, Nolan. 2015. In Calvary, what is the significance of the opening quote by St Augustine? ScreenPrism, no. 29. http://screenprism.com/insights/article/in-cavlary-what-is-the-significanceof-the-opening-quote-by-st.-augustine.

Moore, Ruairi. 2014. Cinema review: Calvary. Film Ireland 11 April 2014. http://filmireland.net/2014/04/11/cinema-review-calvary/. 
Mroz, Matilda. 2016. Framing loss and figuring grief in Pawel Pawlikowski's Ida. Screening the Past, no. 41. http://www.screeningthepast.com/2016/10/framing-loss-and-figuring-grief-inpawel-pawlikowskis-ida/.

Neale, Steve, 2000. Genre and Hollywood. London: Routledge.

O'Rawe, Desmond. 2003. At home with horror: Neil Jordan's gothic variations. Irish Studies Review 11, no. 2: 189-198.

O'Riordan, Alan. 2014. Another weird western as McDonagh and Gleeson reunite in Calvary. Irish Examiner 8 April 2014. http://www.irishexaminer.com/lifestyle/artsfilmtv/artsvibe/anotherweird-western-as-mcdonagh-and-gleeson-reunite-in-calvary-264586.html.

Probyn, Elspeth. 2010. Writing shame. In The affect theory reader, edited by Melissa Gregg and Gregory J. Seigworth, 71-90. London: Duke University Press.

Rueschmann, Eva. 2005. Out of place: Reading (post) colonial landscapes as gothic space in Jane Campion's films. Post Script 24, nos. 2-3: 8-21.

Singer, Ben. 2001. Melodrama and modernity: Early sensational cinema and its contexts. New York: Columbia University Press.

Wigley, Samuel. 2014. Soutane impact: Brendan Gleeson and John Michael McDonagh on Calvary. BFI Film Forever 23 April 2014. http://www.bfi.org.uk/news-opinion/newsbfi/interviews/soutane-impact-brendan-gleeson-john-michael-mcdonagh-calvary.

Williams, Linda. 1998. Melodrama revised. In Refiguring American film genres: History and theory, edited by Nick Browne, 42-88. Berkeley: University of California Press. 